\title{
Common variable immunodeficiency misdiagnosed as Crohn Disease
}

\author{
Daniella Moore ${ }^{1 *}$, Fabiane Dias$^{1}$, Eliane Esberard ${ }^{1}$, Jorge Mugayar ${ }^{1}$, Marcia Costa ${ }^{1}$, Simone Pestana ${ }^{2}$, \\ Jose Laerte Boechat ${ }^{1}$, Rossana Rabeloº ${ }^{2}$ Amanda Seba ${ }^{3}$ \\ From 3rd WAO International Scientific Conference (WISC) 2014 \\ Rio de Janeiro, Brazil. 6-9 December 2014
}

\section{Background}

Common variable immunodeficiency (CVID) is one of the most common primary immunodeficiency in adults and is characterized by defective antibody production, low levels of serum immunoglobulins and increased susceptibility to infection. About $20 \%$ of developed different gastrointestinal pathology. But also the pathology of the gastrointestinal tract in patients with CVID showed a wide spectrum of histological patterns which could mimic many conditions such as inflammatory bowel disease.

\section{Objective}

The presented case highlights the importance of the evaluation of primary immunodeficiency in patients with chronic gastrointestinal disorders.

\section{Case report}

JRLM, 38 years, male, natural from Rio de Janeiro, Brazil, with a history of recurrent respiratory infections during childhood, begins to presented diarrhea (3-4 episodes of loose stools /day) in 2004 without mucus or blood. The colonoscopy showed moderate erosive pancolitis and a nodular ileitis. It was therefore decided to start treatment with mesalazine. In 2005 the colonoscopy was repeated and the patient received the diagnosis of Crohn's Disease and mesalazine was replaced by azathioprine, however the control of diarrhea was not obtained. In 2013 the patient begun treatment in Antonio Pedro Hospital where the colonoscopy was repeated and showed inespecific pancolitis and the endoscopic aspect was not suggestive of Crohn's disease. The stool examination for parasites showed the presence of Giardia lamblia and
Blastocystis hominis and the treatment with metronidazole and ivermectin control the diarrhea. In that time, screening tests for serum immunoglobulin were requested and showed $\mathrm{IgG}=212 \mathrm{mg} / \mathrm{dl}$ (751-1555), $\operatorname{IgA}=$ $<6,67 \mathrm{mg} / \mathrm{dl}(82-453)$ and $\mathrm{IgM}=10.2 \mathrm{mg} / \mathrm{dl}(46-304)$. The patient was diagnosed with common variable immunodeficiency and started treatment with prophylactic amoxicillin and intravenous immunoglobulin with remarkable improvement.

\section{Discussion}

Several studies have documented increased incidence of inflammatory bowel disease in CVID patients. Some patients require in addition to intravenous immunoglobulin replacement therapy, steroids or immunosuppressive drugs to control diarrhea. However our patient showed improvement only with the prophylactic amoxicillin and intravenous immunoglobulin therapy. The chronic diarrhea and the colonoscopy findings mimic the presence of inflammatory bowel disease and mislead the physician for a period and lead to the exclusive treatment of inflammatory bowel disease.

\section{Consent}

Written informed consent was obtained from the patient for publication of this abstract and any accompanying images. A copy of the written consent is available for review by the Editor of this journal.

\section{Authors' details}

${ }^{1}$ Universidade Federal Fluminense, Brazil. ${ }^{2}$ Hospital Universitário Antonio Pedro, Brazil. ${ }^{3}$ Clementino Fraga Filho Hospital, Federal University of Rio De Janeiro, Brazil.

${ }^{1}$ Universidade Federal Fluminense, Brazil

Full list of author information is available at the end of the article 
Published: 8 April 2015

doi:10.1186/1939-4551-8-S1-A267

Cite this article as: Moore et al: Common variable immunodeficiency misdiagnosed as Crohn Disease. World Allergy Organization Journal 2015 8(Suppl 1):A267.

Submit your next manuscript to BioMed Central and take full advantage of:

- Convenient online submission

- Thorough peer review

- No space constraints or color figure charges

- Immediate publication on acceptance

- Inclusion in PubMed, CAS, Scopus and Google Scholar

- Research which is freely available for redistribution

Submit your manuscript at www.biomedcentral.com/submit

() BioMed Central 